\title{
Pelatihan Kader Kesehatan pada Remaja di SMAN 1 Sukamara Kalimantan Tengah
}

\author{
${ }^{1}$ Jenny Oktarina \\ ${ }^{1}$ STIKes Borneo Cendekia Medika \\ ${ }^{1}$ Email : oktarina.jenny@yahoo.co.id
}

\begin{abstract}
ABSTRAK
Remaja merupakan suatu tahap perkembangan dari masa anak-anak menuju masa dewasa akan terjadi perubahan fase kehidupan dalam fisik, fisiologis. Seseorang akan dikatakan sebagai remaja diawali pada usia 11-12 tahun dan berakhir pada usia $18-21$ tahun. Usia remaja menurut WHO adalah 10-19 tahun (WHO, 2012). Di Indonesia menurut BKKBN batasan usia remaja 10-24 tahun (Situmorang, 2003) batasan usia remaja adalah umur 10-19 tahun dan belum kawin (Depkes, 2010). Menurut Dinas Kesehatan RI, tahap perkembangan pada remaja dibagi atas 3 tahapan yakni : remaja awal (10-14 tahun), remaja tengah (15-16 tahun) dan remaja akhir (17-19 tahun). Masa remaja ditandai dengan perubahan - perubahan fisik, yang berdampak terhadap perubahan psikologis. Tanda tanda perubahan fisik pada masa remaja terjadi dalam konteks pubertas yakni kematangan organ organ seks dan kemampuan reproduktif yang bertumbuh dengan cepat yang disebut dengan "growth spurt".

Sasaran dari Pengabdian Masyarakat ini adalah siswa-siswi di SMAN 1 Sukamara. Mengumpuikan peserta pelatihan dan diberi penjelasan tujuan dari pelatihan yang dilaksanakan. Menyampaikan materi tentang KKR. Membuat forum diskusi dan tanya jawab serta sharing pengalaman yang pernah dilakukan tetang KKR. Mengevaluasi materi yang telah diberikan pada saat pelatihan. Peiaksanaan Kegiatan Pelatihan KKR di SMAN 1 Sukamara tahun 2018 diikuti oleh 20 orang peserta. Kegiatan pelatihan untuk para kader kesehatan remaja dirasakan bermanfaat bagi para siswa-siswi untuk meningkatkan pengetahuan dan informasi tentang KKR dalam lingkup sekolah dan masyarakat. Dari hasil evaluasi setelah pelatihan berlangsung yang dilakukan secara lisan mayoritas $70 \%$ mengatakan senang dan mengharapkan kalau ada pelatihan lagi. Kegiatan pelatihan dikatakan berhasil bisa dilihat hasil evaluasi secara keseluruhan baik dari jumlah peserta bisa mencapai 20 orang peserta yang hadir, dan hasil evaluasi terahkir dari tanya jawab ternyata $70 \%$ bisa memahami materi yang disampaikan. Kegiatan Pelatihan KKR di SMAN 1 Sukamara Tahun 2018 dimulai dengan pembukaan dan registrasi dilanjutkan dengan pemberian materi tentang KKR dalam sekolah, dan dilanjutkan dengan demonstrasi kegiatan KKR dalam sekolah.
\end{abstract}

\section{Kata kunci : Remaja, Kader, Kesehatan}

\begin{abstract}
A teenager is a stage of development of the course of childhood to adulthood will happen a change of phase of life in physic, physiological .Someone would was said to be an teenagers started at the age of 12 years and ended when she was 18-21 years.According to the world health organisation is early adolescence 10-19 years has announced, 2012 ). In indonesia according to limit bkkbn early adolescence 10-24 years ( situmorang, 2003) limits early adolescence is the age of 10-19 years and has had no husband (ministry of finance, 2010). According to the local office of health, stage of development in adolescents comprises of 3
\end{abstract}


steps : (10-14 year) into early adolescence, of central teenagers 15-16 year) and teenager 17 to 19 years ) contract was due to end. Adolescence characterized change in physical, which has the effect of psychological on changes in. The sign of change in physical during adolescence happened in the context of puberty namely ripeness organ reproduktif sex organs and the ability of growing quickly and it is called growth spurt.

The target groups of devotion the community this is the students in sman 1 sukamara. The participants of the training and mengumpuikan and give them explanation the purpose of training that have been carried out. Given the lectures about kkr.Make the forum of discussion and a question and answer session and sharing experience that ever been used about kkr.Evaluate a material that has been given during the training. Continued operating while under kkr training activities in sman 1 sukamara 2018 followed by 20 participants. Training activities for the teen health cadres perceived beneficial for the students to increase knowledge and information about school and the community $k \mathrm{kr}$ in scope. From the evaluation after training take place who made an oral the majority $70 \%$ says were happy and that there are training again. Be assessed as being successful training activities can be seen in the overall good of the evaluation of the number of participants can reach 20 participants who attended, and the evaluation results terahkir of a question and answer session it turns out that $70 \%$ able to understand the material that was delivered.Kkr training activities in sman 1 sukamara 2018 begins with an opening and continued by the provision of registration to the topic on kkr in schools, and has been continued by a demonstration kkr activities in schools.

Key words: teens, cadres, health

\section{Pendahuluan}

Remaja merupakan suatu tahap perkembangan dari masa anak-anak menuju masa dewasa akan terjadi perubahan fase kehidupan dalam fisik, fisiologis (WHO, 2010). Seseorang akan dikatakan sebagai remaja diawali pada usia 11-12 tahun dan berakhir pada usia 18 - 21 tahun (Kaplan, 2008). Usia remaja menurut WHO adalah 10-19 tahun (WHO, 2012).

Di Indonesia menurut BKKBN batasan usia remaja 10-24 tahun (Situmorang, 2003) batasan usia remaja adalah umur 10-19 tahun dan belum kawin (Depkes, 2010). Menurut Dinas Kesehatan RI, tahap perkembangan pada remaja dibagi atas 3 tahapan yakni : remaja awal (10-14 tahun), remaja tengah (15-16 tahun) dan remaja akhir (17-19 tahun) (BKKBN, 2010). Masa remaja ditandai dengan perubahan - perubahan fisik, yang berdampak terhadap perubahan psikologis. Tanda tanda perubahan fisik pada masa remaja terjadi dalam konteks pubertas yakni kematangan organ organ seks dan kemampuan reproduktif yang bertumbuh dengan cepat yang disebut dengan "growth spurt" (Mar'at, 2008).

Dalam undang-undang Republik Indonesia Nomor 23 Tahun 1992 tentang kesehatan pasal 17 dinyatakan bahwa kesehatan anak diselenggarakan untuk mewujutkan pertumbuhan dan perkembangan anak dan kesehatan anak dilakukan melalui peningktan kesehatan anak dalam kandungan, masa bayi, masa balita, usia pra sekolah dan usia sekolah. Selanjutnya dalam pasal 45 dinyatakan bahwa kesehatan sekolah diselenggarakan untuk meningkatkan kemampuan hidup sehat peserta didik dalam lingkungan hudup sehat sehingga peserta didik dapat belajar, tumbuh dan berkembang secara harmonis dan optimal menjadi sumber daya manusia yang berkualitas.

Kader Kesehatan Remaja (KKR) adalah peserta didik yang diperlukan guru guna ikut serta melaksanakan sebagaian usaha pelayanan kesehatan terhadap diri 
sendiri, keluarga, dan teman - teman, serta sekolah secara umum. Kader kesehatan harus telah mendapatkan pelatihan dari petugas Puskesmas atau Tim Pembina UKS.

Disamping itu kesehatan sekolah juga diarahkan untuk memupuk kebiasaan hidup sehat agar memiliki pengetahuan, sikap dan keterampilan untuk melaksanakan prinsip hidup sehat aktif berpartisipasi dalam usaha peningkatan kesehatan, baik di sekolah, rumah tangga maupun dalam lingkungan masyarakat. Konsep hidup sehat yang tercermin pada perilaku sehat dalam lingkungan sehat perlu diperkenalkan seawall mungkin pada generasi penerus dan selanjutnya dihayati dan diamalkan. Peserta didik bukanlah lagi semata-mata sebagai objek pembangunan kesehatan melainkan sebagai subjek dan dengan demikian diharapkan mereka dapat berperan secara sadar dan bertanggung jawab dalam pembangunan kesehatan. Anak sekolah tingkat SMA atau sederajat memasuki usia remaja dimana periode ini terjadi pertumbuhan dan perkembangan yang pesat baik fisik, psikologis maupun intelektual.

\section{Metode}

Sasaran dari Pengabdian Masyarakat ini adalah siswa-siswi di SMAN 1 Sukamara. Mengumpuikan peserta pelatihan dan diberi penjelasan tujuan dari pelatihan yang dilaksanakan. Menyampaikan materi tentang KKR. Membuat forum diskusi dan tanya jawab serta sharing pengalaman yang pernah dilakukan tetang KKR. Mengevaluasi materi yang telah diberikan pada saat pelatihan.

\section{Hasil}

Peiaksanaan Kegiatan Pelatihan KKR di SMAN 1 Sukamara tahun 2018 diikuti oleh 20 orang peserta. Kegiatan pelatihan untuk para kader kesehatan remaja dirasakan bermanfaat bagi para siswa-siswi untuk meningkatkan pengetahuan dan informasi tentang KKR dalam lingkup sekolah dan masyarakat. Dari hasil evaluasi setelah pelatihan berlangsung yang dilakukan secara lisan mayoritas $70 \%$ mengatakan senang dan mengharapkan kalau ada pelatihan lagi. Kegiatan pelatihan dikatakan berhasil bisa dilihat hasil evaluasi secara keseluruhan baik dari jumlah peserta bisa mencapai 20 orang peserta yang hadir, dan hasil evaluasi terahkir dari tanya jawab ternyata $70 \%$ bisa memahami materi yang disampaikan. Disamping dari jumlah peserta yang melampaui target keberhasilan juga bisa ditunjukkan dengan pelaksanaan sesuai dengan jadwal sehingga kegiatan penyuluhan dapat berjalan dengan terlib dan lancar.

Gambaran Skenario Program Kegiatan yang dilaksanakan

a. Kegiatan ini merupakan kegiatan Pelatihan KKR di SMAN 1 Sukamara Tahun 2018

b. Kegiatan pelatihan ini diisi dengan materi tentang KKR dalam lingkungan sekolah

\section{Pembahasan}

Berdasarkan jadwal yang telah tersusun, maka urutan pelaksanaan dan hasil yang diperoleh dalam kegiatan ini adalah sebagai berikut:

Kegiatan Pelatihan KKR di SMAN 1 Sukamara Tahun 2018 dimulai dengan pembukaan dan registrasi dilanjutkan dengan pemberian materi tentang KKR dalam sekolah, dan dilanjutkan dengan demonstrasi kegiatan KKR dalam sekolah.

\section{Kesimpulan dan Saran Kesimpulan}

Kegiatan Pelatihan Kader Kesehatan Remaja di SMAN 1 Sukamara Tahun 2016 dirasa sangat bermanfaat untuk para siswasiswi untuk meningkatkan pengetahuan dan informasi siswa-siswi dalam mengantisipasi kegiatan KKR dalam 
sekolah, serta untuk meningkatkan kemandirian pada kader sekolah.

\section{Saran}

Perlu diadakan kegiatan pelatihan serupa dengan tema yang bervariasi. Setiap peserta setelah selesai mengikuti penyuluhan diharapkan mampu mengaplikasikan ilmu yang didapatkan.

\section{Daftar Pustaka}

Kementerian Kesehatan RI, (2010). Rencana Strategis Kementerian Kesehatan Tahun 2010-2014: Jakarta.

Mar'at. (2008). Sikap Manusia, Perubahan, Serta Pengukuran. Ghalia Indonesia : Jakarta.

Bambang Wahyudi. (2002). Manajemen Sumber Daya Manusia. Bandung: Sulita.

WHO. 2010. The World Health Report 2010.

http://www.who.int./whr/2010/ en/index.html Akses 18 Juni $\underline{2015}$ 